\title{
Arctic marine photoautotrophic picoplankton
}

\author{
John Clegg Smith, Trevor Platt, W. K. W. Li, E. P. W. Horne, W. G. Harrison, \\ D. V. Subba Rao and B. D. Irwin
}

Marine Ecology Laboratory, Bedford Institute of Oceanography, P. O. Box 1006, Dartmouth Nova Scotia B2Y 4A2, Canada

\begin{abstract}
Abundance and activity of picoplankton (here defined as cells passing a $1 \mu \mathrm{m}$ Nuclepore screen) were studied in northern Foxe Basin, eastern Canadian Arctic. Substantial proportions (10 to $70 \%$ ) of the chlorophyll a content, ribulose-1,5-bisphosphate carboxylase activity (RuBPC, E.C. 4.1.1.39) and autofluorescent bodies present in whole seawater samples passed a $1 \mu \mathrm{m}$ screen in intact, photoautotrophic particles. A smaller fraction (10 to $25 \%$ ) of the light-dependent ${ }^{14} \mathrm{C}$ fixation was found in this picoplankton fraction, the difference possibly explained by a selective effect of screening on photosynthetic activity rather than by heterotrophic uptake of algal exudates. About $10 \%$ of the whole sample RuBPC was found to pass a $0.2 \mu \mathrm{m}$ diameter screen, indicating the presence of autotrophy in marine ultramicrobacteria (femtoplankton). A potential for growth in the femtoplankton fraction was also indicated by substantial fixation of tritiated nucleic acid precursors into macromolecules.
\end{abstract}

\section{INTRODUCTION}

It has become increasingly apparent that very small organisms (less than $1 \mu \mathrm{m}$ in diameter) constitute an important fraction of the photoautotrophic biomass of the sea. Holmes and Anderson (1963) demonstrated for Puget Sound waters that about $35 \%$ of the photoautotrophically fixed ${ }^{14} \mathrm{C}$ passed a $0.45 \mu \mathrm{m}$ pore diameter Millipore filter and was retained by a $0.22 \mu \mathrm{m}$ Millipore filter while Saijo (1964), also using Millipore filters, showed that up to $37 \%$ of the ${ }^{14} \mathrm{C}$ fixed in light bottles in the Indian Ocean was associated with particles between 0.8 and $0.45 \mu \mathrm{m}$ in diameter. The extent to which this production might be due either to the retention of cell fragments by the smaller filters or to the heterotrophic uptake of radioactive algal exudates was unclear, however. Berman (1975) reported for the Gulf of California that about $25 \%$ of the post-fractionated chlorophyll and apparent light-dependent ${ }^{14} \mathrm{C}$ fixing activity passed a $1 \mu \mathrm{m}$ Nuclepore filter, but concluded, based on a personal communication from Azam, that this was due to chloroplast fragments incapable of photosynthesis.

Similarly, Harrison et al. (1977) showed for a small flagellate dominated community in Saanich Inlet that $18 \%$ of the chlorophyll and $25 \%$ of the photoassimilated ${ }^{14} \mathrm{C}$ passed a $1 \mu \mathrm{m}$ Nuclepore filter. Subsequently, Azam and Hodson (1977) found for samples off Scripps pier and the California Bight that from 10 to $40 \%$ of the chlorophyll in whole seawater samples passed into $1 \mu \mathrm{m}$ Nuclepore filtrates and that, on enrichment, these filtrates produced 2 to $3 \mu \mathrm{m}$ microflagellates which were filterable through $1 \mu \mathrm{m}$ Nuclepore screens but which were not observable in glutaraldehyde-fixed $1 \mu \mathrm{m}$ filtrates. Azam and Hodson (1977) also showed that these $1 \mu \mathrm{m}$-filterable organisms photoassimilated ${ }^{14} \mathrm{CO}_{2}$ at rates correlated with the chlorophyll content of the filtrate. Larsson and Hagstrom (1982) documented for the northern Baltic Sea that the biomass of cells $<2 \mu \mathrm{m}$ in diameter could account for as much as $25 \%$ of the total phytoplankton biomass, but they attributed about half of the ${ }^{14} \mathrm{C}$ assimilation in this fraction to heterotrophic re-fixation of algal exudates.

The size fraction between 2.0 and $0.2 \mu \mathrm{m}$ diameter has been called 'picoplankton' (Sieburth et al., 1978) and direct microscopical observations show that amongst the constituents are chroococcacean cyanobacteria (Johnson and Sieburth, 1979; Waterbury et al., 1979) and prasinophytes (Johnson and Sieburth, 1982). These findings are supported by an analysis of picoplankton pigments (Yentsch, 1983). We have previously shown for the eastern tropical Pacific Ocean (Li et al., 1983) and sub-tropical Atlantic Ocean (Platt et al., 1983), that up to $90 \%$ of the chlorophyll biomass, up to $80 \%$ of the photoautotrophic inorganic carbon 
fixation and up to $85 \%$ of the ribulose-1,5bisphosphate carboxylase activity (RuBPC, E.C. 4.1.1.39, a principle indicator of autotrophy; Whittenbury and Kelly, 1977), were attributable to viable, photoautotrophic particles which passed a $1 \mu \mathrm{m}$ Nuclepore screen but which were retained either by a Whatman GF/F glass fiber filter or a $0.2 \mu \mathrm{m}$ Nuclepore screen. Optical observations by epifluorescent microscopy indicated that these particles were largely orange-fluorescing coccoid cyanobacteria ( $\mathrm{Li}$ et al., 1983). These have subsequently been shown to possess the characteristic peripheral thylakoids (Subba Rao, pers. comm.). However, many cyanobacteria are thermophilic (Allen and Stanier, 1968), and Waterbury and Watson (1979) hypothesized on the basis of the seasonal changes in their abundance in temperate waters that they might be excluded from polar seas. The principle objective of the present study was to assess the role of picoplankton in polar primary production.

It is also clear that viable organisms are capable of passing $0.2 \mu \mathrm{m}$ Nuclepore filters (MacDonell and Hood, 1982). This fraction has been referred to as 'femtoplankton' (Sieburth et al., 1978) or 'ultramicrobacteria' (Torella and Morita, 1981) and may contain about $10 \%$ of the total bacteria (Zimmermann, 1977). There is no information concerning the possibility of autotrophy in the femtoplankton fraction and there is uncertainty whether these organisms are actively growing or are starved, dormant stages (MacDonell and Hood, 1982; Torella and Morita, 1981). A further objective of this study was to determine whether femtoplankton are present in polar waters and whether they exhibit any potential for autotrophy or growth.

All experiments performed in Foxe Basin were with pre-fractionated samples. We noted on analysis that the relative amounts of photosynthetic variables accounted for by the $<1 \mu \mathrm{m}$ fraction were less than for particulates or carboxylating enzyme activities. We present data from a subsequent cruise to the Azores in which the distribution of photosynthetic parameters in the $<1 \mu \mathrm{m}$ fraction were compared in terms of pre- and postfractionation procedures and discuss the question of whether these differ because of a selective effect of the filtration process on photosynthesis or because of the uptake of labelled algal exudates by heterotrophic picoplankton.

\section{MATERIALS AND METHODS}

Sampling location and methods. Experiments were conducted during late August and early September 1981 on an oceanographic cruise onboard C.S.S. 'Baffin' to the eastern Canadian Arctic. Station locations

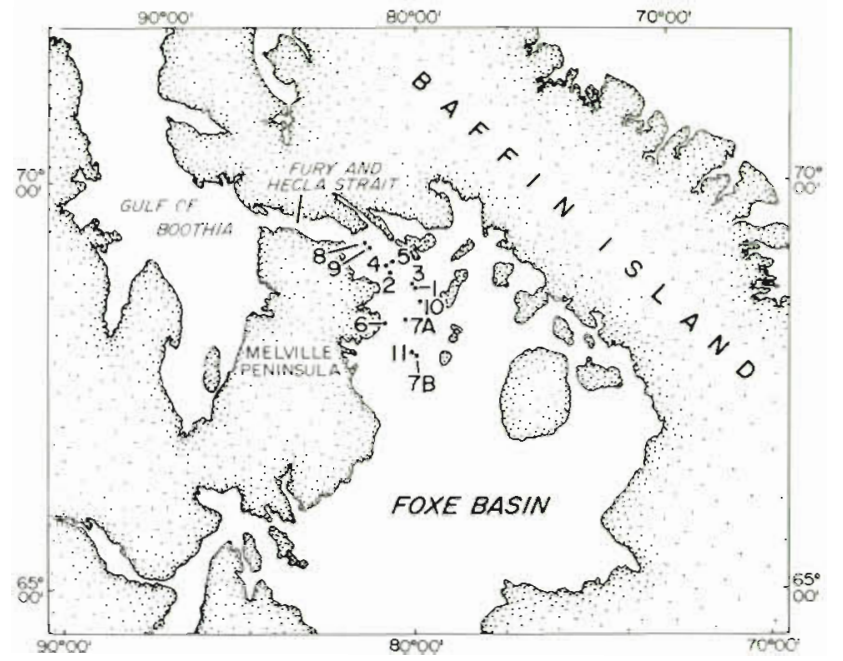

Fig. 1. Map showing northern Foxe Basin, Fury and Hecla Straits and adjacent regions of the Gulf of Boothia. Locations of sampling stations are indicated

are shown on Fig. 1. Water samples for physiological experiments and determination of the various biomass parameters were collected with 301 Niskin bottles. For the picoplankton fraction, a volume of sample water was screened through a $1 \mu \mathrm{m}$ filter and experimental aliquots were drawn from this filtrate. These were subsequently filtered onto GF/F filters either after an experimental period, or immediately, in the case of particulate samples. The unfractionated sample was filtered directly onto GF/F filters.

We have found (unpubl.) that $0.2 \mu \mathrm{m}$ Nuclepore screens retain about $15 \%$ more RuBPC than do GF/F filters and that the latter are roughly equivalent to $0.4 \mu \mathrm{m}$ Nuclepore screens. The manufacturer of $\mathrm{GF} / \mathrm{F}$ filters states that these filters will retain particles down to $0.7 \mu \mathrm{m}$, but this seems very conservative in our experience. Since about $85 \%$ of the $<1 \mu \mathrm{m}$ RuBPCcontaining particles are retained by $G F / F$ filters and their flow rates and sample volume capacity are so much greater than $0.2 \mu \mathrm{m}$ Nuclepore screens, we settled on the GF/F filter for general size fractionation and primary production studies. In order to use $0.2 \mu \mathrm{m}$ Nuclepores routinely it would be necessary to reduce sample volumes substantially and to increase ${ }^{14} \mathrm{C}$ specific activities and the purity of stock solutions accordingly.

Physical and chemical environmental parameters. Continuous profiles of temperature and salinity were obtained with a Guildline model 8770 portable CTD. Inorganic phosphate samples were stored frozen at $-20^{\circ} \mathrm{C}$ and later analysed by the technique of Murphy and Riley (1962).

Biomass and photosynthetic parameters. Chlorophyll was determined by the fluorometric method of Holm-Hansen et al. (1965) on samples which had been 
extracted overnight in $85 \%$ acetone at $0^{\circ} \mathrm{C}$ in the dark. RNA, DNA and POC concentrations were measured using the techniques described in Irwin et al. (1980). The ${ }^{14} \mathrm{C}$ method described by Strickland and Parsons (1972) was used for in situ productivity measurements and time course studies. Time course experiments were incubated in tanks on deck at ambient (near in situ) temperatures under natural light conditions. The method of Irwin et al. (1982) was used to determine the relation between irradiance and photosynthesis; photosynthetic parameters for these experiments were calculated using the equation of Platt et al. (1981), and the fitting procedures described in Gallegos and Platt (1981). Experiments were conducted to show the proportional distribution of ${ }^{14} \mathrm{C}$ into photosynthetic end products (lipid, protein and polysaccharides) into both the whole sample and the $<1 \mu \mathrm{m}$ fraction over a diel cycle. The methods used are described in Li et al. (1980) and Li and Platt (1982). Samples for cell counts were preserved with glutaraldehyde plus paraformaldehyde, concentrated on $0.2 \mu \mathrm{m}$ Nuclepore filters, frozen $\left(-20^{\circ} \mathrm{C}\right)$ and later examined by fluorescence microscopy (excitation, $365 \mathrm{~nm}$; emission, $450 \mathrm{~nm}$ ).

Carboxylating enzyme assay. The assay methods for RuBPC, phosphoenolpyruvate carboxylase (PEPC, E.C. 4.1.1.31) and phosphoenolpyruvate carboxykinase (PEPCK, E.C. 4.1.1.49) were in vivo (or in situ in the usage of Sols et al., 1974) procedures in which the cells in the water sample were concentrated on a filter and then made permeable to the substrates of the enzymes and other small molecules. The utility of this approach has been demonstrated for the regulatory enzyme phosphofructokinase in toluene-permeabilized Escherichia coli (Sols et al., 1974) and in cross-linked, digitonin-permeabilized mammalian erythrocytes (Aragon et al., 1980); the kinetic properties and behaviour of this enzyme when assayed in permeable cells were much more in accord with physiological observations on intact cells than when assayed in vitro. Similarly, RuBPC has been shown to exhibit a much lower (more physiological) $\mathrm{Km}$ within the chloroplast than in vitro (Bahr and Jensen, 1974) and similar results were obtained for RuBPC in the freeze-thaw permeabilized cells of eucaryotic algae (Mukerji and Morris, 1976). RuBPC in photosynthetic bacteria and cyanobacteria has also been studied in toluene-permeabilized cells (Tabita et al., 1978; Storro and McFadden, 1983). The assays for RuBPC and PEPC used in this laboratory are based on those of Mukerji and Morris (1976) except that instead of freezing the cells in liquid $\mathrm{N}_{2}, 1.5 \mathrm{M}$ glycerol (Syrett, 1973) was used to render them permeable (Smith et al., 1983). For this study, the assays were further modified by changing the $\mathrm{pH}$ from 8.0 to 7.5 , the concentration of Tris buffer from 0.4 to $0.1 \mathrm{M}$ and the $\mathrm{HCO}_{3}^{-}$concentration from 50 to $25 \mathrm{mM}$. Additionally,
L- $\alpha$-lysophosphatidylcholine (Sigma, type 1, $0.25 \mathrm{mg}$ / $1.3 \mathrm{ml}$ reaction mixture) was added to further increase the permeability of the cells. The use of this agent to render eucaryotic cells permeable to nucleic acid precursors has been described by Miller et al. $(1978,1979)$ and Castellot et al. (1979). Here, L- $\alpha$-lysophosphatidylcholine increased the measured activities of all enzymes by 20 to $25 \%$. Remaining details of the RuBPC and PEPC assays are given by Smith et al. (1983). The assay method for PEPCK was similar. The incubation mixture consisted of $1.1 \mathrm{ml}$ of the following: Tris buffer $(\mathrm{pH}$ 7.5, $100 \mathrm{mM}), \mathrm{MnCl}_{2} \cdot 4 \mathrm{H}_{2} \mathrm{O}$ (2 mM), ADP (5 mM), EDTA (0.78 mM), $\mathrm{NaHCO}_{3}(25 \mathrm{mM})$, glycerol (1.5 M), L- $\alpha$-lysophosphatidylacholine (Sigma, type 1, $0.25 \mathrm{mg}$ ) and PEP ( $5 \mathrm{mg}$, Sigma, $\mathrm{Na}_{3}$ salt). To this were added $200 \mu \mathrm{l}$ of $\mathrm{NaH}^{14} \mathrm{CO}_{3}$ solution $(5 \mu \mathrm{Ci}$ ). The samples were incubated for about $1 \mathrm{~h}$ at $25^{\circ} \mathrm{C}$ in a slowly reciprocating shaking incubator (Julabo). Termination of the reaction, removal of unfixed ${ }^{14} \mathrm{C}$ and the composition of the scintillation cocktail have been described previously (Smith et al., 1983). Samples were counted with a Beckman LS100 liquid scintillation spectrometer using the channels ratio method of quench correction.

These assays have been tested on a variety of organisms in the laboratory and on natural samples. Based on chlorophyll content, the substrate concentrations we use in field studies are in a 5 to 50 fold excess of those required to saturate the enzymes. RuBP has been shown to inhibit the rate of activation of spinach RuBPC by $\mathrm{Mg}^{++}$and $\mathrm{CO}_{2}$ in vitro (Jordan and Chollet, 1983). This does not appear to be a problem in the RuBPC assay used in this study in which preincubation (10 min) with $\mathrm{Mg}^{++}$and $\mathrm{HCO}_{3}^{-}$apparently gives a fully activated preparation, the activity of which is not decreased by increases in RuBP concentration. Moreover, the reactions are linear for a least $2 \mathrm{~h}$ in field samples and show no lag phenomenon. Blanks (duplicate) containing no substrates were run in all cases. These contained counts which depended only on the particular lot of ${ }^{14} \mathrm{C}$ used (presumably acid stable impurities) and not on the biomass involved. Blanks were subtracted from the experimental values.

\section{Nucleotide uptake by femtoplankton}

Two 11 aliquots of the sample were placed in glass bottles and inoculated with $60 \mu \mathrm{Ci}$ of either ${ }^{3} \mathrm{H}$-TTP (tritiated thymidine triphosphate) or ${ }^{3} \mathrm{H}$-UTP (tritiated uridine triphosphate) and incubated at $2.5^{\circ} \mathrm{C}$ (in situ temperature $=1^{\circ} \mathrm{C}$ ) for $2 \mathrm{~h}$. At the end of the incubation, portions of the samples were serially filtered through Nuclepore filters: $1,0.8,0.6,0.4,0.2,0.1$ and $0.08 \mu \mathrm{m}$. Each filter was then washed with GF/F-filtered sea water and placed in $2.5 \mathrm{ml}$ of cold, $5 \%$ 
trichloroacetic acid. After 30 min in an ice bath, the Nuclepore filters were frozen in the TCA solution in a glass vial until the ship returned to the laboratory ( $2 \mathrm{mo}$ ). These were then thawed on ice and the Nuclepore filter plus the TCA solution were filtered onto a $\mathrm{GF} / \mathrm{F}$ filter. The vial was rinsed twice with $2.5 \mathrm{ml}$ of cold $5 \%$ TCA and the washings filtered onto the GF/F filter which was then rinsed once with $2.5 \mathrm{ml}$ of cold $5 \%$ of TCA and once with $5 \mathrm{ml}$ of cold, absolute ethanol and sucked dry. The Nuclepore and GF/F filters were then placed in sealed scintillation vials with $1 \mathrm{ml}$ of Protosol (New England Nuclear) and heated $\left(55^{\circ} \mathrm{C}\right)$ for $1 \mathrm{~h}$ to dissolve the Nuclepore filter and solubilize the retentates. The cocktail was completed with $50 \mu \mathrm{l}$ of glacial acetic acid plus $10 \mathrm{ml}$ of Econofluor (New England Nuclear) and counted on a Beckman LS3133 liquid scintillation spectrometer using the external standard method of quench correction.

We have not been able to get eucaryotic algae to take up uridine, thymidine, UTP or TTP in the laboratory (unpublished) and assume that all the uptake of nucleoside triphosphates found in Foxe Basin samples was by bacteria. UTP and TTP would normally be hydrolyzed in the periplasmic space and taken up as uridine and thymidine (Hochstadt, 1974), but in a pilot study (unpublished), we found that the triphosphates were incorporated by natural samples at greater rates than the non-phosphorylated compounds. This was based on the assumption that the environmental concentration of all these nucleosides was essentially zero and that adding equal amounts of labelled compounds would result in equal specific activities. If uridine and thymidine were present in significant amounts, this could account for the apparent greater rates of uptake of the phosphorylated compounds. Alternatively, the paradigm for nucleoside uptake by these organisms needs to be re-examined. We chose to use the phosphorylated forms in this study because of the greater apparent sensitivity of the assay.

\section{RESULTS}

\section{Physical oceanography of Foxe Basin}

Arctic water from the Gulf of Boothia passes southward through Fury and Hecla Straits and thence along the eastern shore of the Melville Peninsula and Igloolik Island (Dunbar, 1951; Campbell and Colin, 1956; Grainger, 1959). Foxe Basin per se is shallow and vertically well-mixed by strong tidal action (Griffiths et al., 1981), a situation unusual in arctic waters, which are usually characterized by pronounced vertical stability (Dunbar, 1958). Near the exit of Fury and Hecla
Straits, however, cold arctic water overlies Foxe Basin water, creating a temperature inversion and imposing a vertical structure on the water column which breaks down with increasing distance southwards (see Fig. 2 A-H).

\section{Particulate concentrations and ratios}

The distribution of organic particulate concentrations between the whole sample and the $<1 \mu \mathrm{m}$ fractions at several stations is given in Table 1 . There

Table 1. Organic particulate concentrations $\left(\mu \mathrm{g}^{-1}\right)$ as retained by Whatman GF/F filters

\begin{tabular}{|c|c|c|c|c|c|}
\hline $\begin{array}{l}\text { Station } \\
\text { (Depth) }\end{array}$ & $\begin{array}{c}\text { Frac- } \\
\text { tion }\end{array}$ & CHLA & POC & RNA & DNA \\
\hline $\begin{array}{c}1 \\
(5 \mathrm{~m})\end{array}$ & $\begin{array}{l}\text { Whole } \\
\quad<1 \mu \mathrm{m} \\
\%<1 \mu \mathrm{m}\end{array}$ & $\begin{array}{r}.22 \\
.08 \\
36.4\end{array}$ & $\begin{array}{l}126 \\
72 \\
57.1\end{array}$ & $\begin{array}{r}1.71 \\
.90 \\
52.6\end{array}$ & $\begin{array}{c}7.10 \\
2.35 \\
33.1\end{array}$ \\
\hline $\begin{array}{c}2 \\
(40 \mathrm{~m})\end{array}$ & $\begin{array}{c}\text { Whole } \\
\quad<1 \mu \mathrm{m} \\
\%<1 \mu \mathrm{m}\end{array}$ & $\begin{array}{r}.78 \\
.09 \\
11.5\end{array}$ & $\begin{array}{c}130 \\
55 \\
42.3\end{array}$ & $\begin{array}{r}4.49 \\
.99 \\
22.0\end{array}$ & $\begin{array}{c}4.89 \\
2.82 \\
57.7\end{array}$ \\
\hline $\begin{array}{c}3 \\
(30 \mathrm{~m})\end{array}$ & $\begin{array}{l}\text { Whole } \\
\quad<1 \mu \mathrm{m} \\
\%<1 \mu \mathrm{m}\end{array}$ & $\begin{array}{r}.29 \\
.21 \\
72.4\end{array}$ & $\begin{array}{l}56 \\
35 \\
62.5\end{array}$ & $\begin{array}{c}1.80 \\
.18 \\
10.0\end{array}$ & $\begin{array}{l}4.47 \\
1.40 \\
31.3\end{array}$ \\
\hline $\begin{array}{c}4 \\
(40 \mathrm{~m})\end{array}$ & $\begin{array}{c}\text { Whole } \\
<1 \mu \mathrm{m} \\
\%<1 \mu \mathrm{m}\end{array}$ & $\begin{array}{r}1.03 \\
.18 \\
17.5\end{array}$ & $\begin{array}{c}144 \\
41 \\
28.5\end{array}$ & $\begin{array}{c}2.34 \\
.18 \\
7.7\end{array}$ & $\begin{array}{r}3.71 \\
.94 \\
25.3\end{array}$ \\
\hline $\begin{array}{c}6 \\
(2 \mathrm{~m})\end{array}$ & $\begin{array}{l}\text { Whole } \\
<1 \mu \mathrm{m} \\
\%<1 \mu \mathrm{m}\end{array}$ & $\begin{array}{r}.44 \\
.10 \\
22.7\end{array}$ & $\begin{array}{c}166 \\
52 \\
31.3\end{array}$ & $\begin{array}{c}3.86 \\
1.80 \\
46.6\end{array}$ & $\begin{array}{l}4.32 \\
- \\
-\end{array}$ \\
\hline $\begin{array}{c}7 \\
(0 \mathrm{~m})\end{array}$ & $\begin{array}{l}\text { Whole } \\
<1 \mu \mathrm{m} \\
\%<1 \mu \mathrm{m}\end{array}$ & $\begin{array}{r}.42 \\
.22 \\
52.4\end{array}$ & $\begin{array}{c}130 \\
68 \\
52.3\end{array}$ & $\begin{array}{c}6.56 \\
1.44 \\
22.0\end{array}$ & $\begin{array}{l}8.08 \\
- \\
-\end{array}$ \\
\hline $\begin{array}{c}9 \\
(40 \mathrm{~m})\end{array}$ & $\begin{array}{l}\text { Whole } \\
\quad<1 \mu \mathrm{m} \\
\%<1 \mu \mathrm{m}\end{array}$ & $\begin{array}{r}1.40 \\
.16 \\
11.4\end{array}$ & $\begin{array}{c}105 \\
56 \\
53.3\end{array}$ & $\begin{array}{c}4.67 \\
1.26 \\
27.0\end{array}$ & $\begin{array}{c}3.58 \\
0.61 \\
17.0\end{array}$ \\
\hline $\begin{array}{c}10 \\
(35 \mathrm{~m})\end{array}$ & $\begin{array}{l}\text { Whole } \\
\quad<1 \mu \mathrm{m} \\
\%<1 \mu \mathrm{m}\end{array}$ & $\begin{array}{c}.48 \\
.18 \\
37.5\end{array}$ & $\begin{array}{l}111 \\
36 \\
32.4\end{array}$ & $\begin{array}{l}3.60 \\
.18 \\
5.0\end{array}$ & $\begin{array}{r}4.09 \\
1.69 \\
41.3\end{array}$ \\
\hline $\begin{array}{c}11 \\
(2 \mathrm{~m})\end{array}$ & $\begin{array}{l}\text { Whole } \\
\quad<1 \mu \mathrm{m} \\
\%<1 \mu \mathrm{m}\end{array}$ & $\begin{array}{r}.84 \\
.22 \\
26.2\end{array}$ & $\begin{array}{c}198 \\
84 \\
42.4\end{array}$ & $\begin{array}{l}3.96 \\
2.88 \\
72.7\end{array}$ & $\begin{array}{c}5.22 \\
3.19 \\
61.1\end{array}$ \\
\hline
\end{tabular}

was a weak tendency for the percentage of total CHLA found in the $<1 \mu \mathrm{m}$ fraction to be lower at stations closer to the mouth of Fury and Hecla Straits $(2,4,9)$ while total CHLA tended to be higher at these stations. The proportion of CHLA in the $<1 \mu \mathrm{m}$ fraction was not affected by depth (Table $3 a-c$ ). The percentages of POC, RNA and DNA in the $<1 \mu \mathrm{m}$ fraction generally were higher than for CHLA and did not show any obvious relation to either sample depth, the density gradient or location within Foxe Basin. 


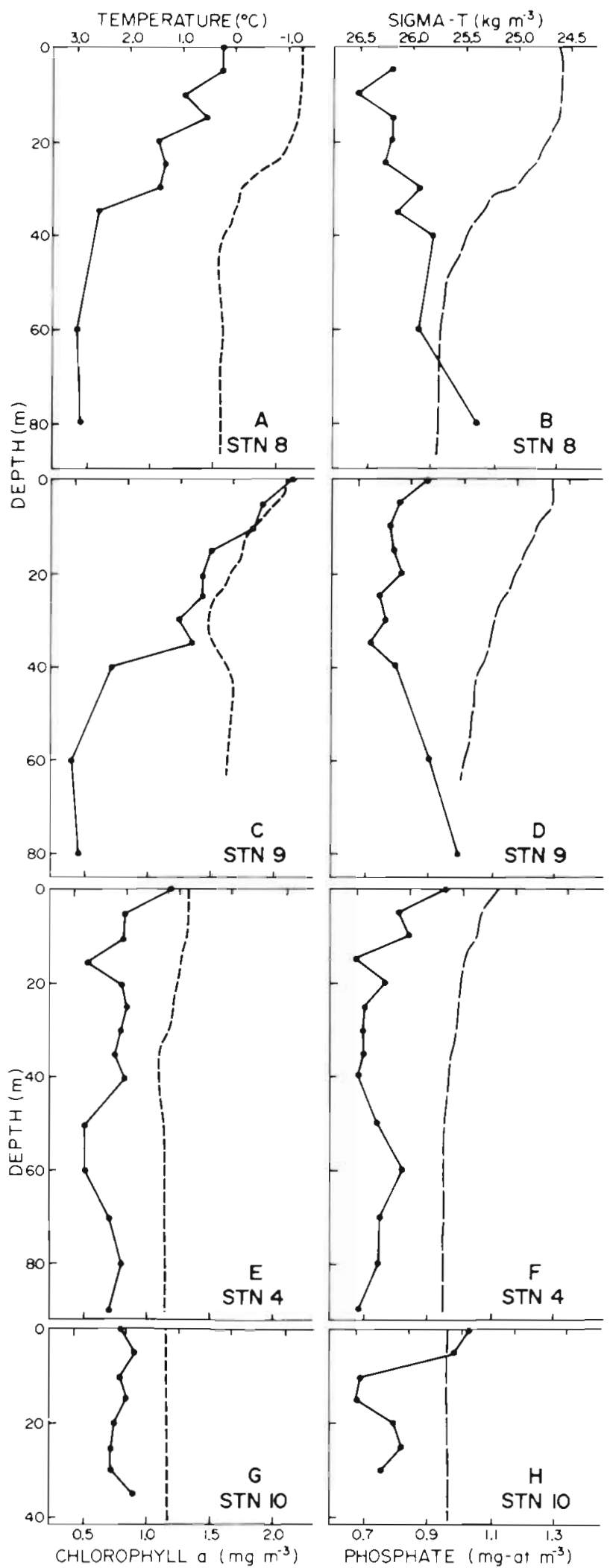

Fig. 2. A, C, E and G: Vertical distributions of chlorophyll $a$ concentration ( $\bullet$ ) and temperature (dashed line) at Stations 8 , 9,4 and 10 , respectively. $B, D, F$ and $H$ : Vertical distributions of phosphate concentration ( $\bullet$ ) and density (dashed line) at Stations $8,9,4$ and 10 , respectively
Ratios of certain particulate concentrations thought to be indices of various physiological processes (Steele and Baird, 1961; Sakshaug and Holm-Hansen, 1977; Dortch et al., 1983; Hegseth and Sakshaug, 1983; Sakshaug et al., 1983) are given in Table 2. The CHLA/POC

Table 2. Ratios of various organic particulate concentrations

\begin{tabular}{|clccc|}
\hline $\begin{array}{c}\text { Station } \\
\text { (depth) }\end{array}$ & $\begin{array}{c}\text { Frac- } \\
\text { tion }\end{array}$ & $\begin{array}{c}10^{3} \mathrm{x} \\
\text { (CHLA/POC) }\end{array}$ & $\begin{array}{c}10^{3} \mathrm{x} \\
\text { (RNA/DNA) }\end{array}$ & $\begin{array}{c}10^{3} \mathrm{x} \\
(\mathrm{DNA} / \mathrm{POC})\end{array}$ \\
\hline 1 & Whole & 1.75 & 240 & 56.35 \\
$(5 \mathrm{~m})$ & $<1 \mu \mathrm{m}$ & 1.11 & 380 & 32.64 \\
2 & Whole & 5.99 & 920 & 37.62 \\
$(40 \mathrm{~m})$ & $<1 \mu \mathrm{m}$ & 1.64 & 350 & 51.27 \\
3 & Whole & 5.18 & 400 & 79.82 \\
$(30 \mathrm{~m})$ & $<1 \mu \mathrm{m}$ & 5.99 & 130 & 40.00 \\
4 & Whole & 7.14 & 630 & 25.76 \\
$(40 \mathrm{~m})$ & $<1 \mu \mathrm{m}$ & 4.39 & 190 & 22.93 \\
6 & Whole & 2.65 & 890 & 26.02 \\
$(2 \mathrm{~m})$ & $<1 \mu \mathrm{m}$ & 1.92 & - & - \\
7 & Whole & 3.23 & 810 & 62.15 \\
$(0 \mathrm{~m})$ & $<1 \mu \mathrm{m}$ & 3.24 & - & - \\
9 & Whole & 13.33 & 1300 & 34.10 \\
$(40 \mathrm{~m})$ & $<1 \mu \mathrm{m}$ & 2.86 & 2070 & 10.89 \\
10 & Whole & 4.33 & 880 & 36.85 \\
$(35 \mathrm{~m})$ & $<1 \mu \mathrm{m}$ & 5.00 & 110 & 46.94 \\
11 & Whole & 4.24 & 760 & 26.36 \\
$(2 \mathrm{~m})$ & $<1 \mu \mathrm{m}$ & 2.62 & 900 & 37.98 \\
& & & & \\
\hline & & & & \\
\hline
\end{tabular}

ratio was low ranging down to $1.11 \times 10^{-3}$ in the $<1 \mu \mathrm{m}$ fraction at Station 1 . This ratio was generally lower in the $<1 \mu \mathrm{m}$ fraction. Samples from stations near the mouth of the straits $(2,4,9)$ tended to have the highest CHLA/POC values, especially in the whole fraction.

Neither the RNA/DNA nor the DNA/POC ratio showed any form of relation to depth, degree of stratification, geographic location or size fraction (Table 2).

\section{Size distribution of carboxylating enzyme activity}

For the 14 distinct samples from various depths at Stations 4, 8 and 9, RuBPC in the $<1 \mu \mathrm{m}$ fraction varied from between 13 and $57 \%$ of the whole sample RuBPC while for PEPCK this range was 27 to $71 \%$ (Table $3 a-c)$.

Results of size fractionation using various combinations of filters to separate RuBPC, PEPC and PEPCK at single depths for 3 different stations are given in Table 4. For Station 1, it is clear that, for all 3 enzymes, adding the activity for the whole sample retained on a $1 \mu \mathrm{m}$ Nuclepore and the activity of $1 \mu \mathrm{m}$ Nuclepore 
Table 3. Multiple-depth study of size-fractionated carboxylating enzyme activity

\begin{tabular}{|c|c|c|c|c|c|c|}
\hline \multirow{2}{*}{$\begin{array}{l}\text { Depth } \\
\text { (m) }\end{array}$} & \multirow[t]{2}{*}{ Fraction } & \multicolumn{5}{|c|}{ Variable } \\
\hline & & RuBPC & PEPCK & CHLA & RuBPC/PEPCK & $\mathrm{Zp}$ \\
\hline \multicolumn{7}{|c|}{ (a) Station 8, Foxe Basin } \\
\hline \multirow[t]{3}{*}{5} & Whole & 29216 & 4741 & 2.42 & 6.2 & A \\
\hline & $<1 \mu \mathrm{m}$ & 6020 & 1368 & 0.16 & 4.4 & \\
\hline & $<1 \mu \mathrm{m}$ as $\%$ of whole & 21 & 29 & 7 & - & \\
\hline \multirow[t]{3}{*}{15} & Whole & 24903 & 4235 & 2.26 & 5.9 & $\mathrm{~B}$ \\
\hline & $<1 \mu \mathrm{m}$ & 7175 & 1383 & 0.24 & 5.2 & \\
\hline & $<1 \mu \mathrm{m}$ as $\%$ of whole & 29 & 33 & 11 & - & \\
\hline \multirow[t]{3}{*}{25} & Whole & 19736 & 3533 & 2.36 & 5.6 & $\mathrm{~B}$ \\
\hline & $<1 \mu \mathrm{m}$ & 4595 & 952 & 0.25 & 4.8 & \\
\hline & $<1 \mu \mathrm{m}$ as $\%$ of whole & 23 & 27 & 11 & - & \\
\hline \multirow[t]{3}{*}{40} & Whole & 14727 & 4392 & 1.02 & 3.4 & $B, C$ \\
\hline & $<1 \mu m$ & 5213 & 1588 & 0.09 & 3.3 & \\
\hline & $<1 \mu \mathrm{m}$ as $\%$ of whole & 35 & 36 & 9 & - & \\
\hline \multirow[t]{3}{*}{60} & Whole & 6014 & 1999 & 0.50 & 3.0 & $\mathrm{C}$ \\
\hline & $<1 \mu \mathrm{m}$ & 796 & 545 & 0.05 & 1.5 & \\
\hline & $<1 \mu \mathrm{m}$ as $\%$ of whole & 13 & 27 & 10 & - & \\
\hline \multicolumn{7}{|c|}{ (b) Station 9, Foxe Basin } \\
\hline \multirow[t]{3}{*}{5} & Whole & 22769 & 3620 & 2.85 & 6.3 & A \\
\hline & $<1 \mu \mathrm{m}$ & 9198 & 1807 & 0.27 & 5.1 & \\
\hline & $<1 \mu \mathrm{m}$ as $\%$ of whole & 40 & 50 & 9 & - & \\
\hline \multirow[t]{3}{*}{25} & Whole & 41334 & 7520 & 1.29 & 5.5 & $\mathrm{~B}$ \\
\hline & $<1 \mu \mathrm{m}$ & 11255 & 2078 & 0.21 & 5.4 & \\
\hline & $<1 \mu \mathrm{m}$ as $\%$ of whole & 27 & 28 & 16 & - & \\
\hline \multirow[t]{3}{*}{40} & Whole & 13406 & 3205 & 1.27 & 4.2 & $\mathrm{~B}, \mathrm{C}$ \\
\hline & $<1 \mu \mathrm{m}$ & 7621 & 1338 & 0.17 & 5.7 & \\
\hline & $<1 \mu \mathrm{m}$ as $\%$ of whole & 57 & 42 & 13 & - & \\
\hline \multirow[t]{3}{*}{55} & Whole & 8482 & 2879 & 1.02 & 2.9 & $\mathrm{C}$ \\
\hline & $<1 \mu \mathrm{m}$ & 1143 & 1647 & 0.09 & 0.7 & \\
\hline & $<1 \mu \mathrm{m}$ as $\%$ of whole & 13 & 57 & 9 & - & \\
\hline \multicolumn{7}{|c|}{ (c) Station 4, Foxe Basin } \\
\hline \multirow[t]{3}{*}{5} & Whole & 17697 & 2399 & 1.09 & 7.4 & A \\
\hline & $<1 \mu \mathrm{m}$ & 4112 & 953 & 0.25 & 4.3 & \\
\hline & $<1 \mu \mathrm{m}$ as $\%$ of whole & 23 & 40 & 23 & - & \\
\hline \multirow[t]{3}{*}{15} & Whole & 22769 & 3620 & 1.12 & 6.3 & $\mathrm{~B}, \mathrm{C}$ \\
\hline & $<1 \mu \mathrm{m}$ & 9198 & 1807 & 0.25 & 5.1 & \\
\hline & $<1 \mu \mathrm{m}$ as $\%$ of whole & 50 & 50 & 22 & - & \\
\hline \multirow[t]{3}{*}{25} & Whole & 18064 & 2097 & 0.90 & 8.6 & $\mathrm{C}$ \\
\hline & $<1 \mu \mathrm{m}$ & 8818 & 1482 & 0.19 & 6.0 & \\
\hline & $<1 \mu \mathrm{m}$ as $\%$ of whole & 49 & 71 & 21 & - & \\
\hline \multirow[t]{3}{*}{40} & Whole & 11644 & 2812 & 0.99 & 4.1 & $\mathrm{C}$ \\
\hline & $<1 \mu \mathrm{m}$ & 5121 & 1026 & 0.28 & 5.0 & \\
\hline & $<1 \mu \mathrm{m}$ as $\%$ of whole & 47 & 36 & 28 & - & \\
\hline \multirow[t]{3}{*}{60} & Whole & 9750 & 1936 & 0.74 & 5.0 & $\mathrm{C}$ \\
\hline & $<1 \mu \mathrm{m}$ & 4871 & 700 & 0.14 & 7.0 & \\
\hline & $<1 \mu \mathrm{m}$ as $\%$ of whole & 50 & 36 & 20 & - & \\
\hline
\end{tabular}


Table 4. Distribution of carboxylating enzyme activity in various size fractions from Foxe Basin

\begin{tabular}{|c|c|c|c|c|c|c|}
\hline Station & Fraction & RuBPC & PEPC & PEPCK & RuBPC/PEPC & RuBPC/PEPCK \\
\hline \multirow[t]{4}{*}{$1(5 \mathrm{~m})$} & Whole on GF/F & 10784 & 826 & 3651 & 13.1 & 3.0 \\
\hline & Whole on $1 \mu \mathrm{m}$ & 4943 & 99 & 1548 & 50.0 & 3.2 \\
\hline & $1 \mu m$ on $G F / F$ & 6541 & 618 & 2305 & 10.6 & 2.8 \\
\hline & $\%<1 \mu \mathrm{m}>\mathrm{GF} / \mathrm{F}$ & 60.7 & 74.8 & 63.1 & & \\
\hline \multirow[t]{3}{*}{$5(40 \mathrm{~m})$} & Whole on $1 \mu \mathrm{m}$ & 12039 & 1528 & 2967 & 7.9 & 4.1 \\
\hline & $1 \mu \mathrm{m}$ on $\mathrm{GF} / \mathrm{F}$ & 14577 & 3305 & 3524 & 4.4 & 4.1 \\
\hline & $\%<1 \mu \mathrm{m}>\mathrm{GF} / \mathrm{F}$ & 54.8 & 68.4 & 54.3 & & \\
\hline \multirow[t]{4}{*}{$7(0 \mathrm{~m})$} & Whole on $3 \mu \mathrm{m}$ & 4960 & 234 & 822 & 21.2 & 6.0 \\
\hline & $3 \mu \mathrm{m}$ on $1 \mu \mathrm{m}$ & 4094 & 308 & 586 & 13.3 & 7.0 \\
\hline & $1 \mu \mathrm{m}$ on $0.2 \mu \mathrm{m}$ & 4815 & 194 & 1864 & 24.8 & 2.6 \\
\hline & $\%<1 \mu \mathrm{m}>0.2 \mu \mathrm{m}$ & 34.7 & 26.4 & 57.0 & & \\
\hline
\end{tabular}

filtrate retained by a $\mathrm{GF} / \mathrm{F}$ gives a very close approximation of the activity of a whole sample retained by a $\mathrm{GF} / \mathrm{F}$. For all 3 enzymes, the proportion of activity in the $<1 \mu \mathrm{m}$ fraction was a little less than twice that for CHLA (36.4\%; Table 1). At Station $7 \mathrm{~B}$, the $<1 \mu \mathrm{m}$ fraction (retained by a $\mathrm{GF} / \mathrm{F}$ ) contained $52.5 \%$ of the whole sample CHLA (Table 1); however, the $<1 \mu \mathrm{m}$ fraction (retained by a $0.2 \mu \mathrm{m}$ Nuclepore) contained a little more than half that proportion of RuBPC and PEPC but about the same proportion of PEPCK. At Station $5,23.2 \%$ of the CHLA was in the $<1 \mu \mathrm{m}$ fraction which, as at Station 1, was about half the proportion of the $<1 \mu \mathrm{m}$ enzymes. PEPC activity relative to other arctic locations and to the reagent blanks was very low in Foxe Basin samples in general, although inoderate levels were observed at Station 5. Where the PEPC levels were low, random measurement errors became significant and the RuBPC/PEPC ratio is probably not very meaningful. Elsewhere, the RuBPC/PEPC and RuBPC/PEPCK ratios tended to be similar or slightly lower in the $<1 \mu \mathrm{m}$ fractions.

At Station 6 we observed the distribution of RuBPC activity in the $<0.4 \mu \mathrm{m}$ fraction (Table 5 ). About $25 \%$ of the total RuBPC activity passed a $0.4 \mu \mathrm{m}$ Nuclepore filter. Of this, $15 \%$ was retained on a $0.2 \mu \mathrm{m}$ filter, while of the $10 \%$ which passed a $0.2 \mu \mathrm{m}$ filter, into the

Table 5. Distribution of RuBPC activity in the less than $0.4 \mu \mathrm{m}$ diameter fraction. Station 6, Foxe Basin

\begin{tabular}{|lcc|}
\hline Fraction & $\begin{array}{c}\text { RuBPC } \\
\mathrm{dpm} \mathrm{I}^{-1} \mathrm{~h}^{-1}\end{array}$ & $\begin{array}{c}\text { \% of total } \\
\text { in fraction }\end{array}$ \\
\hline Whole on $0.4 \mu \mathrm{m}$ & 4407 & 75.4 \\
$0.4 \mu \mathrm{m}$ on $0.2 \mu \mathrm{m}$ & 867 & 14.8 \\
$0.2 \mu \mathrm{m}$ on $0.1 \mu \mathrm{m}$ & 287 & 4.9 \\
$0.1 \mu \mathrm{m}$ on $0.08 \mu \mathrm{m}$ & 287 & 4.9 \\
Total & 5848 & - \\
\hline
\end{tabular}

femtoplankton fraction, half was retained by a $0.1 \mu \mathrm{m}$ filter and half passed a $0.1 \mu \mathrm{m}$ filter and was retained by a $0.08 \mu \mathrm{m}$ filter.

The uptake of labelled nucleic acid precursors $\left({ }^{3} \mathrm{H}\right.$ TTP, ${ }^{3} \mathrm{H}$-UTP) into various size categories was also observed at Station 6 (Table 6). It is clear that the peak

Table 6. Uptake of tritiated TTP and UTP into macromolecules by various fractions of the plankton at Station 6 in Foxe Basin

\begin{tabular}{|c|c|c|c|c|}
\hline & $\begin{array}{l}\text { Sample or } \\
\text { filtrate } \\
(\mu \mathrm{m})\end{array}$ & $\begin{array}{l}\text { Filter size } \\
\text { for retentate } \\
\quad(\mu \mathrm{m})\end{array}$ & $\begin{array}{c}\text { TTP } \\
\text { uptake } \\
(\text { dpm l-1) }\end{array}$ & $\begin{array}{c}\text { UTP } \\
\text { uptake } \\
\left(\text { dpm } ~^{-1}\right)\end{array}$ \\
\hline \multicolumn{5}{|c|}{ Measured values } \\
\hline A & Whole sample & 1.0 & 4191 & 92548 \\
\hline B & 1.0 & 0.8 & 2417 & 10851 \\
\hline $\mathrm{C}$ & 0.8 & 0.6 & 4304 & 13254 \\
\hline $\mathrm{D}$ & 0.6 & 0.4 & 17066 & 150254 \\
\hline E & 0.4 & 0.2 & 6436 & 34593 \\
\hline $\mathrm{F}$ & 0.2 & 0.1 & 9370 & 10568 \\
\hline G & 0.1 & 0.08 & 8322 & 5833 \\
\hline \multicolumn{5}{|c|}{ Computed from above } \\
\hline $\mathrm{H}$ & 1.0 & 0.2 & 30223 & 208952 \\
\hline I & 0.2 & 0.08 & 17692 & 16401 \\
\hline $\mathrm{J}$ & 1.0 & 0.08 & 47915 & 225353 \\
\hline $\mathrm{K}$ & \multicolumn{2}{|c|}{ Sum of all fractions } & 52106 & 317901 \\
\hline \multicolumn{3}{|c|}{$(\mathrm{A} / \mathrm{K}) \cdot 100$} & $8.04 \%$ & $29.11 \%$ \\
\hline \multicolumn{3}{|c|}{$(\mathrm{H} / \mathrm{K}) \cdot 100$} & $58.00 \%$ & $65.73 \%$ \\
\hline \multicolumn{3}{|c|}{$(\mathrm{I} / \mathrm{K}) \cdot 100$} & $33.95 \%$ & $5.16 \%$ \\
\hline \multicolumn{3}{|c|}{$(\mathrm{J} / \mathrm{K}) \quad 100$} & $91.96 \%$ & $70.89 \%$ \\
\hline \multicolumn{5}{|c|}{$\mathrm{H}=\mathrm{B}+\mathrm{C}+\mathrm{D}+\mathrm{E}_{;} \mathrm{I}=\mathrm{F}+\mathrm{G}, \mathrm{J}=\mathrm{H}+\mathrm{F}+\mathrm{G}}$. \\
\hline
\end{tabular}

uptake for each substrate corresponds to a nominal particle diameter of about $0.5 \mu \mathrm{m}$. As shown below, the proportion of the activity present in the $<1 \mu \mathrm{m}$ fraction is more similar to those for the particulates and carboxylating enzymes than to that for the various photosynthetic parameters. Most notable are the significant 
values in the $<0.2 \mu \mathrm{m}$ fractions (femtoplankton) with $34 \%$ of the TTP-uptake occurring in this size range.

\section{Fluorescence microscopy}

Glutaraldehyde/paraformaldehyde-fixed cells autofluorescing yellow or red were enumerated at 5 depths (corresponding to those in Table $3 b$ ) at Station 9 (Table 7). Two fractions were considered, the whole

Table 7. Epifluorescence microscope counts of particles autofluorescing pale yellow or red. Station 9, Foxe Basin

\begin{tabular}{|clcc|}
\hline $\begin{array}{c}\text { Depth } \\
(\mathrm{m})\end{array}$ & Whole on $1 \mu \mathrm{m}$ & $1 \mu \mathrm{m}$ on $0.2 \mu \mathrm{m}$ & $\begin{array}{c}\text { F in }<1 \mu \mathrm{m} \\
\text { fraction }\end{array}$ \\
\hline 5 & $1.44 \times 10^{6} 1^{-1}$ & $1.33 \times 10^{6} 1^{-1}$ & 48 \\
15 & 2.05 & 2.05 & 50 \\
25 & 1.64 & 1.94 & 54 \\
40 & 0.82 & 0.92 & 53 \\
55 & 1.85 & 1.64 & 47 \\
\hline
\end{tabular}

sample as retained by a $1 \mu \mathrm{m}$ filter and $1 \mu \mathrm{m}$ filtrate as retained on a $0.2 \mu \mathrm{m}$ filter. At all depths, approximately $50 \%$ of the autofluorescing cells were contained in the $<1 \mu \mathrm{m}$ fraction. There appeared to be a slight sub-surface maximum in numbers of fluorescing cells for both fractions.

\section{Photosynthesis-irradiance experiments}

The relation between photosynthesis and irradiance was determined for the whole and $<1 \mu \mathrm{m}$ size fractions for a surface sample at Station $7 \mathrm{~B}$. These relations are shown in Fig. $3 \mathrm{~A}$ and B, and the parameters describing these curves are given in Table 8. Photoinhibition was slight in both fractions with high $I_{B}$ 's characteristic of a surface sample (Platt et al., 1980) but was less for the $<1 \mu \mathrm{m}$ fraction. The variance of the estimates of the P-I parameters was greater for the $<1 \mu \mathrm{m}$ fraction; the coefficient of variation was about twice that for the whole fraction. The values of $\mathrm{P}_{\mathrm{m}}^{\mathrm{b}}$ (assimilation number; light-saturated, chlorophyllnormalized photosynthetic rate) and $\mathrm{P}_{\mathrm{s}}^{\mathrm{b}}$ in the $<1 \mu \mathrm{m}$ fraction were 19.4 and $18.7 \%$, respectively, of those for the whole fraction (Table 8 ).

This was so despite the fact that $52.4 \%$ of the CHLA (Table 1) and about $34.7 \%$ of the RuBPC (Table 4) were in the $<1 \mu \mathrm{m}$ fraction. The chlorophyll-normalized photosynthetic efficiency $\left(\alpha^{b}\right.$, initial slope [light-limited portion] of the light saturation curve) for the $<1 \mu \mathrm{m}$ fraction was $17.7 \%$ of that for the whole fraction. When $P_{m}$ and $\alpha$ were considered on a unit

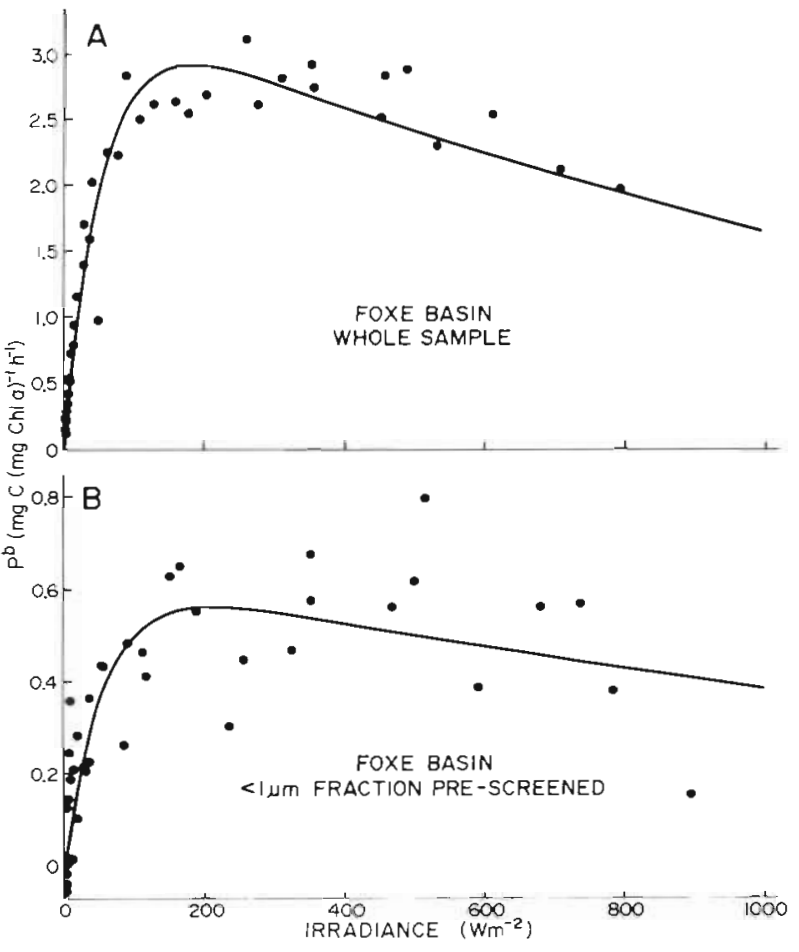

Fig. 3. A and B: Relation between photosynthesis and irradiance for the whole sample and the pre-fractionated $<1 \mu \mathrm{m}$ fraction, respectively, at Station 7 in Foxe Basin. Note difference in scale on ordinates

Table 8. Parameters of photosynthesis-irradiance curves for pre-incubation fractionated samples. Station 7 , Foxe Basin

\begin{tabular}{|c|c|c|c|c|c|c|}
\hline Fraction & $P_{s}^{b}$ & $\mathrm{P}_{\mathrm{m}}^{\mathrm{b}}$ & $\alpha^{\mathrm{b}}$ & $\mathrm{P}_{\mathrm{m}}$ & $\alpha$ & $\mathrm{I}_{\mathrm{B}}$ \\
\hline Whole & 3.47 & 2.90 & 0.060 & 1.22 & 0.025 & 1343 \\
\hline$<1 \mu \mathrm{m}$ & 0.65 & 0.56 & 0.011 & 0.12 & 0.0023 & 1858 \\
\hline$\%<1 \mu \mathrm{m}$ & 18.7 & 19.4 & 17.7 & 10.2 & 9.2 & \\
\hline \multicolumn{7}{|c|}{$\begin{array}{l}\text { Units: } P_{s}^{b}, P_{m}^{b}: \mu g C(\mu g C H L A)^{-1} h^{-1} ; P_{m}-\mu g C^{-1} h^{-1} \\
\alpha^{b}: \mu g C(\mu g C H L A)^{-1} h^{-1}\left(W^{-2}\right)^{-1} \\
\alpha: \mu g C l^{-1} h^{-1}\left(W^{-2}\right)^{-1} ; I_{B}-W m^{-2}\end{array}$} \\
\hline
\end{tabular}

sample volume basis (dimensionally analogous to CHLA and RuBPC; Table 8), however, the difference between CHLA, RuBPC and these photosynthetic parameters nearby doubled.

Other experiments were carried out in which bottles were incubated in tanks on deck exposed to ambient light (which was always low, however, so that the ${ }^{14} \mathrm{C}$ fixation rates obtained were probably light-limited). The incubation times were about $6 \mathrm{~h}$ in the middle of the day. The average whole fraction value for chlorophyll-normalized ${ }^{14} \mathrm{C}$ production rates $\left(\mathrm{P}^{\mathrm{b}}\right)$ at six stations was $1.18 \mathrm{mg} \mathrm{C} \mathrm{mg} \mathrm{CHLA}{ }^{-1} \mathrm{~h}^{-1}$ while that for the $<1 \mu \mathrm{m}$ fraction was 0.29 or $24.6 \%$ of the total, roughly comparable to the P-I curve data. When taken 
on a sample volume basis, the $<1 \mu \mathrm{m}$ fraction accounted for only $4.5 \%$ of the total.

\section{Distribution of ${ }^{14} \mathrm{C}$ in photosynthetic products}

A 20 h time course study of the distribution of ${ }^{14} \mathrm{C}$ into the end products of photosynthesis in the whole and $<1 \mu \mathrm{m}$ fractions was carried out at Station 10 using sample water from $35 \mathrm{~m}$ (Table 1). The results of these experiments are shown in Fig. 4. Uptake of ${ }^{14} \mathrm{C}$ into all components (TOTAL, Fig. 4) of both fractions was light-dependent, net-fixation ceasing with darkness at about 1900. This was also true of uptake into the lipid fraction. The rate of appearance of ${ }^{14} \mathrm{C}$ in protein was, however, unaffected by darkness and it is probable that the source of this ${ }^{14} \mathrm{C}$ was carbon incorporated into the polysaccharide fraction during the light period. After the light period, the proportion of ${ }^{14} \mathrm{C}$ incorporated into the total, lipid and polysaccharide components of the $<1 \mu \mathrm{m}$ fraction was about 15 to $18 \%$ of that for the whole fraction (unit sample volume basis). This proportion was nearer to $10 \%$ for protein and this did not change significantly during the dark period. In the same sample, $37.5 \%$ of the CHLA was found in the $<1 \mu \mathrm{m}$ fraction (Table 1 ).

\section{Effects of fractionating previous to incubation}

Data comparing the effects of fractionating the sample either preceding (pre-fractionation) or following (post-fractionation) the incubation period are given in Table 9 and Fig. 5 A-D for photosynthesis-irradiance experiments carried out in July 1982 near the Azores (Platt et al., 1983). It is clear that the photosynthetic capacity $\left(\mathrm{P}_{\mathrm{m}}^{\mathrm{b}}, \mathrm{P}_{\mathrm{m}}\right)$ is diminished about 2.5 -fold by the pre-fractionation procedure. However, neither the photosynthetic efficiency $(\alpha)$ nor the photoinhibition indicator $\left(I_{B}\right)$ were affected significantly. It can also be seen from Table 9 that either the pre- or post-fractionated $<1 \mu \mathrm{m}$ value when added to the post-fractionated $>1 \mu \mathrm{m}$ value gave a reasonable approximation of the post-incubation whole sample value. This was not the case for $\mathrm{P}_{\mathrm{m}}$ where only the post-fractionated $<1 \mu \mathrm{m} \mathrm{P}_{\mathrm{m}}$ value could be used in this manner.

\section{DISCUSSION}

\section{Hydrographic considerations}

The stratification of the water column and the temperature inversion observed at the northernmost stations $(8,9$; Fig. 2 A-D) in Foxe Basin result from the inflow of relatively fresh, cold arctic water through Fury and Hecla Straits from the Gulf of Boothia; this water is probably the main source of the high CHLA concentrations found by Platt et al. (submitted) for these locations. The strong, tidal mixing in Foxe Basin disperses the incoming phytoplankton cells throughout the water column, a process which is essentially complete at the more southerly, isothermal stations (e.g. Station 10; Fig. 2 G). At Stations 8 and 9, however, the surface mixed layer, which is much shallower at Station 9, consists of water from Fury and Hecla Straits, while the water forming the density gradient consists of an admixture of this and Foxe Basin water. Below
Fig. 4. Time course of carbon uptake by whole sample $(\bullet)$ and pre-fractionated $<1 \mu \mathrm{m}$ fraction $(0)$ into all acid stable components (TOTAL) and into the polysaccharide, protein and lipid subfractions. Note difference in scale on ordinates. Station 10, Foxe Basin
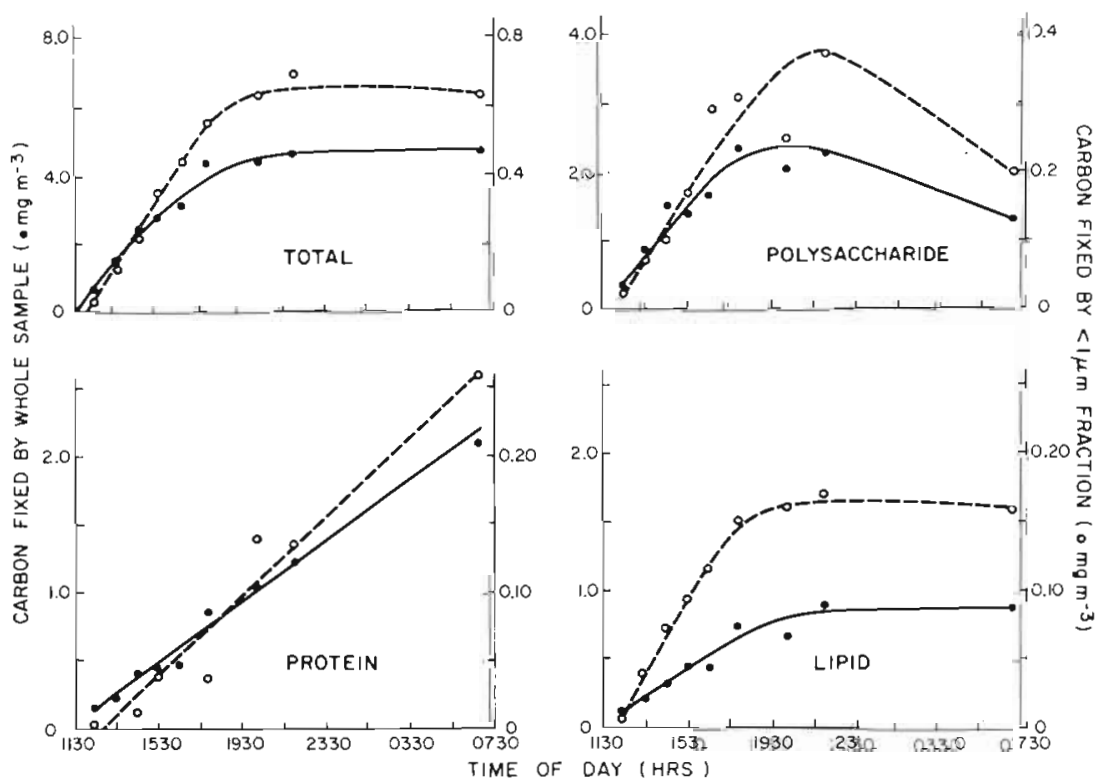
Table 9. Comparison of post- and pre-incubation fractionation procedures for photosynthesis-irradiance experiments at Station $17(88 \mathrm{~m})$ near the Azores, July 1982

\begin{tabular}{|c|c|c|c|c|c|c|}
\hline Method & Fraction & ATP & CHLA & $P_{m}$ & $\alpha$ & $I_{B}$ \\
\hline \multirow{7}{*}{$\begin{array}{l}\text { Post-incubation } \\
\text { fractionation }\end{array}$} & Whole & 0.26 & 0.54 & 0.3372 & 27.0 & 125.2 \\
\hline & $>1 \mu \mathrm{m}$ & 0.18 & 0.23 & 0.1282 & 9.2 & 202.7 \\
\hline & $<1 \mu \mathrm{m}$ & 0.08 & 0.26 & 0.2686 & 22.9 & 144.4 \\
\hline & $110^{2} \times(>1 \mu \mathrm{m}+<1 \mu \mathrm{m})$ & $100 \%$ & $90.7 \%$ & $117.7 \%$ & $118.9 \%$ & - \\
\hline & whole & & & & & \\
\hline & $10^{2} \times(>1 \mu \mathrm{m}) /$ whole & $69.2 \%$ & $42.6 \%$ & $38.0 \%$ & $34.1 \%$ & - \\
\hline & $\left.10^{2} \times i<1 \mu \mathrm{m}\right) /$ whole & $30.8 \%$ & $48.1 \%$ & $79.7 \%$ & $84.7 \%$ & - \\
\hline \multirow{3}{*}{$\begin{array}{l}\text { Pre-incubation } \\
\text { fractionation }\end{array}$} & $<1 \mu \mathrm{m}$ & - & - & 0.1011 & 20.5 & 145.4 \\
\hline & $10^{2} \times(\operatorname{Pre}<1 \mu \mathrm{m})$ & - & - & $37.6 \%$ & $89.8 \%$ & - \\
\hline & (Post $<1 \mu \mathrm{m})$ & & & & & \\
\hline \multicolumn{7}{|c|}{ Units: ATP and CHLA, $\mu \mathrm{gl}^{-1} ; \mathrm{P}_{\mathrm{m}}, \mu \mathrm{gCl^{-1 }} \mathrm{h}^{-1} ; \alpha ; \mathrm{ngCl}^{-1} \mathrm{~h}^{-1}\left(\mathrm{Wm}^{-2}\right)^{-1} ; \mathrm{I}_{\mathrm{B}}, \mathrm{Wm}^{-2}$} \\
\hline
\end{tabular}

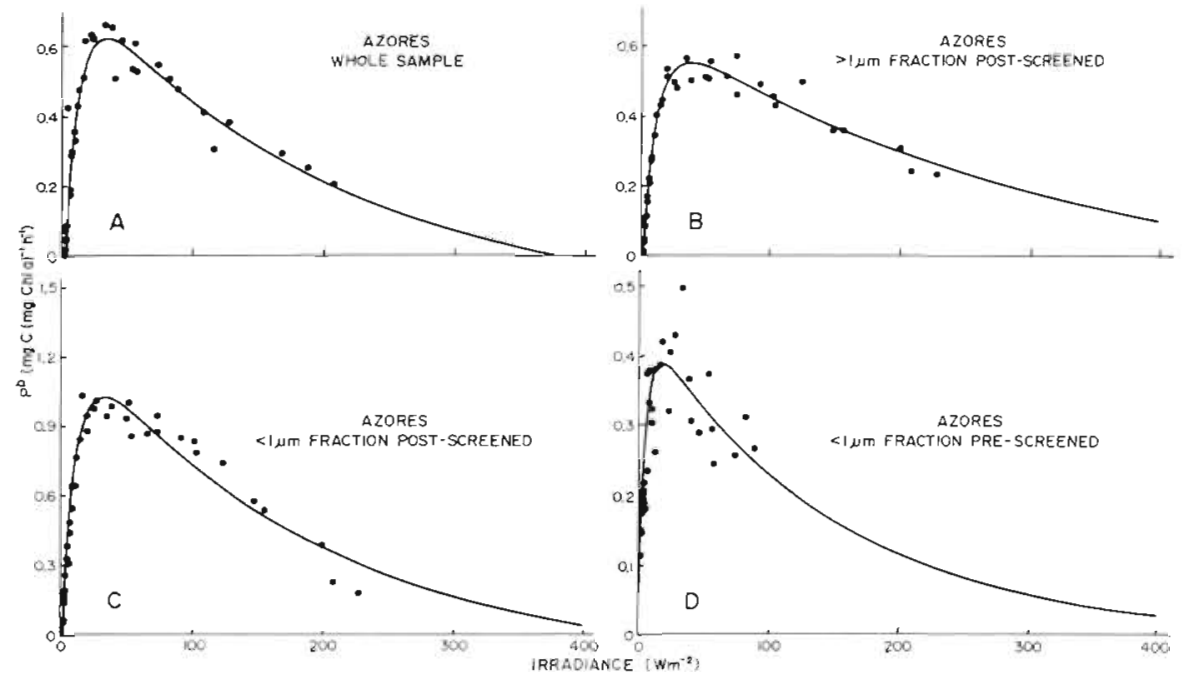

Fig. 5. A, B, C, D: Effects of various fractionation procedures on the relation between photosynthesis and irradiance for a sample from $88 \mathrm{~m}$ near the Azores. A: whole sample; $B$ : post-fractionated $>1 \mu \mathrm{m}$ fraction; C: post-fractionated $<1 \mu \mathrm{m}$ fraction; D: prefractionated $<1 \mu \mathrm{m}$ fraction. Note difference in scale on ordinates

the density gradient $(\approx 45 \mathrm{~m})$, lies Foxe Basin water, similar to that at Station 10, but which may have been isolated from the surface for some period. Station 4 (Fig, 2 E, F) is clearly intermediate in its characteristics; the sharply defined, cold mixed layer at Stations 8 and 9 has been replaced by a slowly changing, warmer gradient to about $40 \mathrm{~m}$ where the water column becomes nearly isothermal and relatively warm.

\section{Particulate concentrations and ratios}

The proportion of CHLA in the $<1 \mu \mathrm{m}$ fraction was lower at stations $(2,4,9)$ nearest the mouth of Fury and Hecla Straits (Table 1) and this did not appear to be influenced by depth or degree of stratification (Table $3 a-c)$. It is likely, therefore, that the proportion of CHLA in the $<1 \mu \mathrm{m}$ fraction depends more on the proportion of Gulf of Boothia water (low in $<1 \mu \mathrm{m}$ CHLA-containing particles) admixed with Foxe Basin water (relatively high in $<1 \mu \mathrm{m}$ CHLA) than on factors such as stratification-dependent photoadaptation (Platt et al., 1982). The proportion of other organic particulates (POC, RNA, DNA) contained in the $<1 \mu \mathrm{m}$ fraction did not correlate with either depth, degree of stratification or location. It seems probable that in view of the strong mixing, the phytoplankton component of these variables may be swamped by large contributions from both detritus (numerous macrophyte fragments being observed in samples) and benthic, heterotrophic microorganisms.

The CHLA/POC values found in this study fell at or below the lower end of the range of values reported by Hegseth and Sakshaug (1983) for dialysis cultures of several diatoms grown under similar conditions of irradiance and temperature. These low values may 
indicate that growth rates were low (Steele and Baird, 1961, 1962), or, more likely, that there were large detrital and non-photosynthetic contributions to the POC component, or both.

The RNA/DNA ratio (Table 2) has been used as an index of growth rate in various small organisms from bacteria (Caldwell, 1950, Neidhardt and Magasanik, 1960 ) to zooplankton (Bamstedt and Skjoldal, 1976 , 1980). The values obtained for this ratio were very low compared to phytoplankton growing under various degrees of nutrient stress (Dortch 1983; Perry et al, in preparation). The only RNA/DNA ratios indicative of even moderate growth were for both fractions at Station 9. The generally low values for the RNA/DNA ratio may have been a result of detrital DNA, but we cannot evaluate this possibility with our data.

In the absence of heterotrophic or detrital DNA the DNA/POC ratio could indicate whether the size fractions differ in the proportion of phytoplankton carbon associated with living matter. It is highly improbable that this criterion was met, but there was no systematic difference between the two size fractions in the DNA/ POC ratio. All that may be concluded from the various indicator ratios is that they are of extremely limited utility in non-ideal situations.

\section{Size distribution of CHLA and carboxylating enzymes}

The fact that the activities in the $>1 \mu \mathrm{m}$ and $<1 \mu \mathrm{m}$ size fractions for all 3 enzymes at Station 1 (Table 4) add up to give a good approximation of the whole sample enzyme activities indicates that the fractionation procedure had no adverse effect on these particular physiological variables. In a subsequent study off the Azores we obtained similar results for CHLA and ATP, the 2 subfractions accounting for 90.7 and $100 \%$, respectively, of the whole sample (Table 9). By the criterion of summation, at least, the data probably give an accurate picture of the distribution of CHLA and carboxylating enzyme activity in the $<1 \mu \mathrm{m}$ size fraction.

It is of particular interest that PEPCK and PEPC activities add up in this manner. PEPCK may be either Initochondrial or cytosolic (Hatch and Osmond, 1976) but PEPC is known to be strictly cytosolic (Spalding et al., 1979; Perrot et al., 1981). Thus if pre-fractionation on the $1 \mu \mathrm{m}$ Nuclepore filters caused, say, break-up of cells and organelles with some subsequent re-sealing in the form of fragments retainable by GF/F filters, then we would expect that the PEPC activities would not add up and that there would be drastic increases in the RuBPC/PEPC ratio in the $<1 \mu \mathrm{m}$ fraction. In fact, the RuBPC/PEPC and RuBPC/PEPCK ratios tend to be similar or to decrease under these circumstances, strongly suggesting that the cells pass the $1 \mu \mathrm{m}$ screen in an intact state. The strength of this argument would be diminished if the majority of the $<1 \mu \mathrm{m}$ photosynthetic organisms were prokaryotic, but Azam and Hodson (1977) and Johnson and Sieburth (1982) have shown that the picoplankton may contain substantial numbers of eukaryotic algae, notably, in the latter study, of prasinophytes in samples as far north as the coast of Iceland.

Thus, for the Foxe Basin samples, including the multiple-depth stations (Table $3 \mathrm{a}-\mathrm{C}$ ) from 10 to $70 \%$ of the RuBPC, PEPC, PEPCK and CHLA were able to pass a $1 \mu \mathrm{m}$ Nuclepore screen within intact particles retainable by $0.2 \mu \mathrm{m}$ Nuclepore or GF/F filters. Epifluorescence microscope counts at Station 9 (Table 6) revealed that similar percentages of autofluorescing cells passed the $1 \mu \mathrm{m}$ screen, the proportion being similar to that for RuBPC (Table $3 b$ ).

Additionally, the data of Table 5 indicate that some RuBPC activity is capable of passing a $0.2 \mu \mathrm{m}$ Nuclepore filter and being retained by $0.1 \mu \mathrm{m}$ or $0.08 \mu \mathrm{m}$ filters. This is strongly suggestive of an autotrophic capability (Whittenbury and Kelly, 1977) in the femtoplankton fraction. Furthermore, these particles appear capable of synthesis of DNA and RNA as shown by the uptake of both TTP and UTP into macromolecules (cold $5 \%$ TCA precipitate) by this fraction (Table 6 ). These findings suggest further study is required especially with the electron microscope. However, what are apparently intact organisms in this size range $(\approx 0.1 \mu \mathrm{m})$ have been illustrated by Sieburth (1979: p. 155, Plate 8-4,E). Zimmerman (1977) has shown that up to $10 \%$ of the total bacteria passes a $0.2 \mu \mathrm{m}$ filter. Definitive evidence that these particles are intact organisms capable of growth and reproduction has been provided in the studies of Torrella and Morita (1981) and MacDonnell and Hood (1982). Whether these organisms are capable of any form of autotrophy and especially whether they possess any photosynthetic capabilities or structures are interesting questions for the future.

\section{Photosynthesis-irradiance experíments}

The results of the photosynthesis-irradiance experiments (Table 8; Fig. 3A, B) and the photosynthetic end products study (Fig. 4, 'TOTAL') clearly show that ${ }^{14} \mathrm{C}$ accumulation by the $<1 \mu \mathrm{m}$ fraction is light-dependent (photosynthetic). The fact that the samples were prescreened eliminates the possibility that the ${ }^{14} \mathrm{C}$ uptake in the small fraction was due to accumulation of ${ }^{14} \mathrm{C}$-labelled exudates from larger phytoplankton.

There are, however, important quantitative discrepancies between the proportions of CHLA, RuBPC, 
PEPC and PEPCK and the proportions of photosynthetic activity present in the $<1 \mu \mathrm{m}$ fraction. At Station 7 for example (Tables 1 and 4), 52.4, 34.7, 26.4 and $57.0 \%$, respectively, of CHLA, RuBPC, PEPC and PEPCK are in the $<1 \mu \mathrm{m}$ fraction whereas for $\mathrm{P}_{\mathrm{m}}$ and $\alpha$ (Table 8 ), the proportions are 10.2 and $9.2 \%$, respectively - a 3 - to 6 -fold difference.

One hypothesis to account for this discrepancy would be that the 'surplus' RuBPC is contained in nonphotosynthetic autotrophs which fix carbon by RuBPC but use an energy source other than light. This seems unlikely in view of Fig. 4 ('TOTAL') which shows that neither the whole nor $<1 \mu \mathrm{m}$ fractions fix sufficient carbon in the dark to suggest that the 'surplus' RuBPC is involved in non-photosynthetic autotrophy. Such a hypothesis clearly cannot account for the 'surplus' chlorophyll either.

Another possibility is that the prescreening selectively disrupts a photosynthetic process while CHLA and the enzymes are unaffected. To test this hypothesis it would be necessary to compare $P_{m}, \alpha$ and photoinhibition in parallel P-I experiments in which one set of samples was screened before and the other after the incubation period. This was not done in Foxe Basin, but an experiment was carried out on a subsequent cruise off the Azores (Table 9; Fig. 5A-D). At the same time, the sum of the $>1$ and $<1 \mu \mathrm{m}$ fractions (post-incubation fractionation) was compared to the whole sample for ATP, CHLA, $\alpha$ and $P_{m}$ (all normalized to sample volume). This sum accounted for 100,90.7, 118.9 and $117.7 \%$ of the respective whole sample values (Table 9). These values are very similar to those for RuBPC $(106.5 \%)$, PEPC $(86.8 \%)$ and PEPCK $(105.5 \%)$ at Station 1 in Foxe Basin (Table 4$)$. In contrast (Table 9), the pre-fractionated $<1 \mu \mathrm{m}$ sample was only $37.6 \%$ of the post-fractionated $<1 \mu \mathrm{m}$ value for $\mathrm{P}_{\mathrm{m}}$ (Table 9). If we convert the $<1 \mu \mathrm{m}$ prefractionated $P_{m}$ value obtained at Station 7 (Table 8 ) by a factor of $1 / .376$, the resulting value of $26.2 \%$ of $P_{m}$ in the $<1 \mu \mathrm{m}$ fraction, is in reasonable accord with RuBPC $(34.7 \%)$. It may thus be possible to attribute a major portion of the discrepancy between the proportions of CHLA and carboxylating enzymes in the $<1 \mu \mathrm{m}$ fraction, on the one hand, and the proportion of $\mathrm{P}_{\mathrm{m}}$ in the $<1 \mu \mathrm{m}$ fraction, on the other, to a selective disturbance of the photosynthetic process caused by the prescreening procedure. This consideration, together with the evidence that RuBPC and PEPC pass $1 \mu \mathrm{m}$ screens in intact particles, suggests to us that, at least at this stage of the seasonal cycle, a significant portion of the primary production in Foxe Basin, and possibly (up to $50 \%$ based on RuBPC data) certain other arctic environments, occurs in photoautotrophic particles able to pass a $1 \mu \mathrm{m}$ pore diameter screen.

We must also consider the possibility that the 2.5 - fold difference in the pre- and post-fractionated $\mathrm{P}_{\mathrm{m}}$ values for the $<1 \mu \mathrm{m}$ fraction at the Azores station resulted from the heterotrophic uptake of ${ }^{14} \mathrm{C}$-labelled algal exudates from the $>1 \mu \mathrm{m}$ fraction. If the lower $\mathrm{P}_{\mathrm{m}}$ in the $<1 \mu \mathrm{m}$ pre-fractionated sample were to be attributed only to the lack of available labelled exudates, then it is difficult to imagine why $\alpha$ and particularly why $I_{B}$ should not be similarly diminished (Table 9), especially in view of the magnitude of the change in $P_{m}$. That is, unless we wish to believe that exudate uptake in the small fraction of this sample was completely photoheterotrophic and exhibited precisely the same photoinhibition characteristics as the small photoautotrophic component, the considerable, hypothetical uptake of exudates by the $<1 \mu \mathrm{m}$, post-fractionated sample should lead to an apparent decrease in photoinhibition (increase in $\mathrm{I}_{\mathrm{B}}$ ) when compared to the pre-fractionated sample. It can be seen in Table 9, however, that no such increase in $I_{B}$ was observed. A similar argument can be applied in the case of $\alpha$, the pre- and post-fractionated $<1 \mu \mathrm{m}$ samples not differing to any extent (Table 9), provided, of course, that neither exudate release nor uptake has a threshold irradiance beyond that which limits photosynthesis. These arguments do not exclude the possibility of heterotrophic uptake of labelled exudates in the $<1 \mu \mathrm{m}$ fraction in the Foxe Basin samples. However, Li et al. (1983) also presented indirect evidence that, in the short-term (hours), the labelling of picoplankton by ${ }^{14} \mathrm{CO}_{2}$ was attributable to direct photosynthesis and not to uptake of radiolabelled organic substances released by larger phytoplankton. Recently, Li (unpubl.) showed that cycloheximide, at a concentration inhibitory to ${ }^{14} \mathrm{CO}_{2}$ labelling in the $>1 \mu \mathrm{m}$ fraction, was not so in the $<1 \mu \mathrm{m}$ fraction: this was construed as evidence that ${ }^{14} \mathrm{C}$ label appearing in the picoplankton arose from procaryotic oxygenic photosynthesis and was not due to a transfer from the $>1 \mu \mathrm{m}$ fraction (i.e. heterotrophic uptake of ${ }^{14} \mathrm{C}$-exudates).

The foregoing considerations suggest, that heterotrophic processes can account for a rather small portion of the difference in $\mathrm{P}_{\mathrm{m}}$ between the pre- and postscreened small fractions. This, in turn, suggests that pre-screening somehow uncouples the light and dark reactions, possibly somewhere in the photosynthetic electron transport chain. These speculations point out a number of possible experimental approaches as well as the need to design definitive experiments to study the phenomenon of exudate uptake and to better quantify the role of picoplankton in primary production in all environments.

The dark loss of ${ }^{14} \mathrm{C}$ from polysaccharides and the dark accumulation of ${ }^{14} \mathrm{C}$ in proteins in both size fractions (Fig. 4) is not inconsistent with the loss of labelled exudates from phototrophs and their subsequent 
refixation by heterotrophs. On the other hand, Kremer (1981) has shown for macrophytic brown algae that PEP which is carboxylated by PEPCK in the light is derived from 3-phosphoglycerate produced in the RuBPC reaction, whereas in the dark, PEP is derived from stored mannitol via the glycolytic pathway. These findings are consistent with the results of the end product's study, the enzymic composition of the cells and with a suggestion of Raven (1974) that PEPCK may serve an anaplerotic role especially as regards the anabolic functions of the tricarboxylic acid cycle. The oxaloacetate produced in the PEPCK reaction can be readily aminated to aspartate (with ATP generation) and incorporated into algal protein in the dark.

\section{LITERATURE CITED}

Allen, M. M., Stanier, R. Y. (1968). Selective isolation of bluegreen algae from water and soil. J. gen. Microbiol. 51 203-209

Aragon, J. J., Feliu, J. E., Frenkel, R. A., Sols, A. (1980). Permeabilization of animal cells for kinetic studies of intracellular enzymes: In situ behavior of the glyolytic enzymes of erythrocytes. Proc. natn. Acad. Sci. U.S.A. 77 : $6324-6328$

Azam, F., Hodson, R. E. (1977). Size distribution and activity of marine microheterotrophs. Limnol. Oceanogr. 22: 492-501

Bahr, J. T., Jensen, R. G. (1974). Ribulose diphosphate carboxylase from freshly ruptured spinach chloroplasts having an in vivo $\mathrm{K}_{\mathrm{m}}\left[\mathrm{CO}_{2}\right]$. Plant Physiol. 53: 39-44

Bamstedt, U., Skjoldal, H. R. (1976). Studies on the deepwater pelagic community of Korsfjorden, western Norway. Adenosine phosphates and nucleic acids in Euchaeta norvegica (Copepoda) in relation to its life cycle. Sarsia 60: $63-80$

Bamstedt, U., Skjoldal, H. R. (1980). RNA concentration of zooplankton: relationship with size and growth. Limnol. Oceanogr. 25: 304-316

Berman, T. (1975). Size fractionation of natural aquatic populations associated with autotrophic and heterotrophic carbon uptake. Mar. Biol. 33: 215-220

Caldwell, P. C., Mackor, E. L., Hishelwood, C. (1950). The ribose nucleic acid content and cell growth of Bact. lactis aerogenes. J. Chem. Soc. 1950: 3151-3155

Campbell, N. J., Collin, A. E. (1956). A preliminary report on some of the oceanographic features of Foxe Basin. Fish. Res. Bd Can. MS Rep. Biol. Stations No. 613: 1-42

Castellot, J. J. Jr, Miller, M. R., Lehtomaki, D. M., Pardee, A. B. (1979). Comparison of DNA replication and repair enzymology using permeabilized baby hamster kidney cells. J. Biol. Chem. 254: 6904-6908

Dortch, Q., Roberts, T L., Clayton, J. R. Ir., Ahmed, S. I. (1983). RNA/DNA ratios and DNA concentrations as indicators of growth rate and biomass in planktonic marine organisms. Mar. Ecol. Prog. Ser. 13: 61-71

Dunbar, M. J. (1951). Eastern arctic waters, Bull. Fish. Res. Bd Can. 88: 1-131

Dunbar, M. J. (1958). Ecological development in polar regions. Prentice-Hall, Englewood Cliffs, New Jersey

Gallegos, C. L., Platt, T. (1981). Photosynthesis measurements on natural populations of phytoplankton: numerical analysis. In: Platt, T. (ed.) Physiological bases of phytoplankton ecology. Can. Bull. Fish. Aquat. Sci. 210: 103-112

Grainger, E. H. (1959). The annual oceanographic cycle at Igloolik in the Canadian Arctic. 1. The zooplankton and physical and chemical observations. J. Fish. Res. Bd Can. 16: 453-501

Griffiths, D. K., Pingree, R. D., Sinclair, M. (1981). Summer tidal fronts in the near-arctic regions of Foxe Basin and Hudson Bay. Deep Sea Res. 28: 865-873

Harrison, W. G., Azam, F., Renger, E. H., Eppley, R. W. (1977). Some experiments on phosphate assimilation by coastal marine plankton. Mar. Biol. 40: 9-18

Hatch, M. D., Osmond, C. B. (1976). Compartmentation and transport in $C_{4}$ photosynthesis. In: Stocking, C. R., Heber, U. (ed.) Transport in plants III. Intracellular interactions and transport processes. Springer-Verlag, Berlin, p. $144-184$

Hegseth, E. N., Sakshaug, E. (1983). Seasonal variation in light- and temperature-dependent growth of marine planktonic diatoms in in situ dialysis cultures in the Trondheimsfjord, Norway $\left(63^{\circ} \mathrm{N}\right)$. J. exp. mar. Biol. Ecol. 67: $199-220$

Hochstadt, J. (1974). The role of the membrane in the utilization of nucleic acid precursors. CRC Crit. Rev. Biochem. 2: $259-310$

Holmes, R. W., Anderson, G. C. (1963). Size fractionation of $\mathrm{C}^{14}$-labelled natural phytoplankton communities. In: Oppenheimer, C. H. (ed.) Marine microbiology. C. C. Thomas Publ., Springfield, Ill., p. 241-250

Holm-Hansen, O., Lorenzen, C. J., Holmes, R. W., Strickland, J. D. H. (1965). Fluormetric determination of chlorophyll. J. Cons. int. Explor. Mer 30: 3-15

Irwin, B., Harrison, W. G., Gallegos, C. L., Platt, T. (1980). Phytoplankton productivity experiments and nutrient measurements in the Labrador Sea, Davis Strait,Baffin Bay and Lancaster Sound from 26 August to 14 September, 1978. Can. Data Rep. Fish. Aquat. Sci. 213: 1-103

Irwin, B., Platt, T., Harrison, W. G., Gallegos, C. L., Lindley, P. (1982). Phytoplankton productivity experiments and nutrient measurements in Ungava Bay, NWT from August 1 to September 3, 1979. Can. Data Rep. Fish. Aquat. Sci. 287: $1-208$

Johnson, P. W., Sieburth, J. McN. (1979). Chroococcoid cyanobacteria in the sea: a ubiquitous and diverse phototrophic biomass. Limnol. Oceanogr. 24: 928-935

Johnson, P. W., Sieburth, J. McN. (1982). In-situ morphology and occurrence of eucaryotic phototrophs of bacterial size in the picoplankton of estuarine and oceanic waters. J. Phycol. 18: 318-327

Jordan, D. B., Chollet, R. (1983). Inhibition of ribulose bisphosphate carboxylase by substrate ribulose 1,5-bisphosphate. J. Biol. Chem. 258: 13752-13758

Kremer, B. P. (1981). Metabolic implications of non-photosynthetic carbon fixation in brown macroalgae. Phycologia 20: $242-250$

Larsson, U., Hagstrom, A. (1982). Fractionated phytoplankton primary production, exudate release and bacterial production in a Baltic eutrophication gradient. Mar. Biol. 67: $57-70$

Li, W. K. W., Glover, H. E., Morris, I. (1980). Physiology of carbon photoassimilation by Oscillatoria thiebautii in the Caribbean Sea. Limnol. Oceanogr. 25: 447-456

Li, W. K. W., Platt, T. (1982). Distribution of carbon among photosynthetic end-products in phytoplankton of the eastern Canadian arctic. J. Phycol. 18: 466-471

Li, W. K. W., Subba Rao, D. V., Harrison, W. G., Smith, J. C., 
Cullen, J. J., Irwin, B., Platt, T. (1983). Autotrophic picoplankton in the tropical ocean. Science, N. Y. 219: 292-295

MacDonell, M. T., Hood, M. A. (1982). Isolation and characterization of ultramicrobacteria from a Gulf Coast estuary. Appl. environ. Microbiol. 43: 566-571

Miller, M. R., Castellot, J. J. Jr., Pardee, A. B. (1978). A permeable animal cell preparation for studying macromolecular synthesis. DNA synthesis and the role of deoxyribonucleotides in S phase initiation. Biochemistry 17: $1073-1080$

Miller, M. R., Castellot, J. J. Jr., Pardee, A. B. (1979). A general method for permeabilizing monolayer and suspension cultured animal cells. Expl Cell Res. 120: 421-425

Mukerji, D., Morris, I. (1976). Photosynthetic carboxylating enzymes in Phaeodctylum tricornutum: assay methods and properties. Mar. Biol. 36: 199-206

Murphy, J., Riley, J. P. (1962). A modified single solution method for the determination of phosphate in natural waters. Analyt. Chem. Acta 27: 31-36

Neidhardt, F. C., Magasanik, B. (1960). Studies on the role of ribonucleic acid in the growth of bacteria. Biochim. biophys. Acta 42: 99-116

Perrot, C., Vidal, J., Burlet, A., Gadal, P. (1981). On the cellular location of phosphoenolpyruvate carboxylase in sorghum leaves. Planta 151: 226-231

Регт, M. J., Talbot, M. C., Smith, J. C., Welschmeyer, N. A. Nitrogen limitation in marine phytoplankton: response of the photosynthetic apparatus. (in prep.)

Platt, T., Gallegos, C. L., Harrison, W. G. (1980). Photoinhibition of photosynthesis in natural assemblages of marine phytoplankton. J. mar. Res. 38: 687-701

Platt, T., Harrison, W. G., Irwin, B., Horne, E. P. W., Gallegos, C. L. (1982). Photosynthesis and photoadaptation of marine phytoplankton in the arctic. Deep Sea Res. 29: $1159-1170$

Platt, T., Subba Rao, D. V., Irwin, B. (1983). Photosynthesis of picoplankton in the oligotrophic ocean. Nature, Lond. 301: $702-704$

Platt, T., Irwin, B., Horne, E. P. W., Smith, J. C. Phytoplankton production in northern Foxe Basin, eastern Canadian arctic. Arctic (submitted)

Raven, J. A. (1974). Carbon dioxide fixation. In: Stewart, W. D. P. (ed.) Algal physiology and biochemistry. University of California Press, Berkeley and Los Angeles, p. 434-455

Saijo, Y. (1964). Size distribution of photosynthesizing phytoplankton in the Indian Ocean. J. oceanogr. Soc. Japan 19: 19-21

Sakshaug, E., Holm-Hansen, O. (1977). Chemical composition of Skeletonema costatum (Grev.) Cleve and Pavlova Iutheri (Droop) Green as a function of nitrate-phosphate-, and iron-limited growth. J. exp. mar. Biol. Ecol. 29: 1-34

Sakshaug, E., Andresen, K., Myklestad, S., Olsen, Y. (1983). Nutrient status of phytoplankton communities in Norwegian waters (marine, brackish, and fresh) as revealed by their chemical composition. J. Plankton Res. 5: 175-196
Sieburth, J. McN. (1979). Sea microbes. Oxford University Press, New York

Sieburth, J. McN., Smetacek, V., Lenz, J. (1978). Pelagic ecosystem structure. Heterotrophic compartments of the plankton and their relationship to plankton size fractions. Limnol. Oceanogr. 23: 1256-1263

Smith, J. C., Platt, T., Harrison, W. G. (1983). Photoadaptation of carboxylating enzymes and photosynthesis during a spring bloom. Prog. Oceanogr. 12: 425-459

Sols, A., Reeves, R. E., Gancedo, C. (1974). Regulation of enzymes in situ. In: Fischer, E. H., Krebs, E. G., Neurath, H., Stadtman, E. R. (ed.) Metabolic interconversion of enzymes 1973. Springer-Verlag, Berlin, p. 393-399

Spalding, M. H., Schmitt, M. R., Ku, S. B., Edwards, G. E. (1979). Intracellular location of some key enzymes of Crassulacean acid metabolism in Sedum praealtum. Pl. Physiol. 63: 738-743

Steele, J. H., Baird, I. E. (1961). Relations between primary production, chlorophyll and particulate carbon. Limnol. Oceanogr. 6: 68-78

Steele, J. H., Baird, I. E. (1962). Carbon-chlorophyll relations in cultures. Limnol. Oceanogr. 7: 101-102

Storro, I., McFadden, B. A. (1983). Ribulose bisphosphate carboxylase/oxygenase in toluene-permeabilized Rhodospirillum rubrum. Biochem. J. 212: 45-54

Strickland, J. D. H., Parsons, T. R. (1972). A practical handbook of seawater analysis, 2nd ed. Bull. Fish. Res. Bd Can. 167: $1-311$

Tabita, F. R., Caruso, P., Whitman, W. (1978). Facile assay of enzymes unique to the Calvin cycle in intact cells, with special reference to ribulose 1,5-bisphosphate carboxylase. Analyt. Biochem. 84: 462-472

Torrella, F., Morita, R. Y. (1981). Microcultural study of bacterial size changes and microcolony formation by heterotrophic bacteria in seawater. Appl. environ. Microbiol, 41: 518-527

Waterbury, J. B., Watson, S. W. (1979). The discovery, distribution and role in primary productivity of a unicellular, marine, planktonic cyanobacterium. In: Annual report, Woods Hole, Oceanographic Institution. Leyden Press, Plymouth, Mass., p. 15-17

Waterbury, J. B., Watson, S. W., Guillard, R. R. L., Brand, L. E. (1979). Widespread occurrence of a unicellular, marine, planktonic cyanobacterium. Nature, Lond. 277: 293-294

Whittenbury, R., Kelly, D. P. (1977). Autotrophy: a conceptual phoenix. Symp. Soc. gen. Microbiol. 27: 121-149

Yentsch, C. S. (1983). A note on the fluorescence characteristics of particles that pass through glass-fiber filters. Limnol. Oceanogr. 28: 597-599

Zimmermann, R. (1977). Estimation of bacterial number and biomass by epifluorescence microscopy and scanning electron microscopy. In: Rheinheimer, G. (ed.) Microbial ecology of a brackish water environment. Springer-Verlag, Berlin, p. 103-120 